\title{
Evaluating gene by sex and age interactions on cardiovascular risk factors in Brazilian families
}

Suely R Giolo ${ }^{1,2^{*}}$, Alexandre C Pereira ${ }^{1}$, Mariza de Andrade ${ }^{3}$, José E Krieger ${ }^{1}$, Júlia P Soler ${ }^{4}$

\begin{abstract}
Background: In family studies, it is important to evaluate the impact of genes and environmental factors on traits of interest. In particular, the relative influences of both genes and the environment may vary in different strata of the population of interest, such as young and old individuals, or males and females.

Methods: In this paper, extensions of the variance components model are used to evaluate heterogeneity in the genetic and environmental variance components due to the effects of sex and age (the cutoff between young and old was 43 yrs). The data analyzed were from 81 Brazilian families (1,675 individuals) of the Baependi Family Heart Study.

Results: The models allowing for heterogeneity of variance components by sex suggest that genetic and environmental variances are not different in males and females for diastolic blood pressure, LDL-cholesterol, and HDL-cholesterol, independent of the covariates included in the models. However, for systolic blood pressure, fasting glucose and triglycerides, the evidence for heterogeneity was dependent on the covariates in the model. For instance, in the presence of sex and age covariates, heterogeneity in the genetic variance component was suggested for fasting glucose. But, for systolic blood pressure, there was no evidence of heterogeneity in any of the two variance components. Except for the LDL-cholesterol, models allowing for heterogeneity by age provide evidence of heterogeneity in genetic variance for triglycerides and systolic and diastolic blood pressure. There was evidence of heterogeneity in environmental variance in fasting glucose and HDL-cholesterol.
\end{abstract}

Conclusions: Our results suggest that heterogeneity in trait variances should not be ignored in the design and analyses of gene-finding studies involving these traits, as it may generate additional information about gene effects, and allow the investigation of more sophisticated models such as the model including sex-specific oligogenic variance components.

\section{Background}

Despite decades of research, the identification of the genetic basis of complex traits remains a challenging assignment, given that these traits can be influenced by a multiplicity of genetic and environmental factors in that each factor is expected to make a small contribution to trait variability. Regarding complex traits, family studies have proven to be useful in the study of the overall contribution of genes to trait variation and in the comparison of heritability between subgroups such as males and females or young and old individuals. In the comparison of heritability by sex, an indication of

\footnotetext{
* Correspondence: giolo@ufpr.br

'Laboratory of Genetics and Molecular Cardiology, Heart Institute, Medical

School of University of Sao Paulo, Sao Paulo, SP, Brazil

Full list of author information is available at the end of the article
}

gene by sex interaction is provided when sex differences in such heritability are observed.

Several studies have investigated the possibility of heterogeneity in genetic effects by age and sex. In a cohort of Sardinians [1], comparisons of heritability by sex and age (cutoff of 42 yrs between young and old individuals) were performed on many cardiovascular and personality traits with sex and age differences in heritability observed for several traits. For diabetes, hypertension, dyslipidemia and abdominal obesity, part of the operational definition of metabolic syndrome, and also for many other traits, sex differences in heritabilities have also been evaluated and described in numerous other studies [2-5]. In general, results from these studies suggest the effect of a gene by sex interaction for some of the traits that were investigated.

\section{(Ciomed Central}


The understanding of the relative importance of both genes and environmental factors for the inter-individual variability of complex traits are paramount for more efficient planning and analysis of mapping and genetic association studies of complex diseases. In fact, the delimitation of a particular stratum of the population, in which the participation of genetic variables has a major importance, may facilitate the identification of small gene effects that may be central to the complex disease causation paradigm.

In this paper, we used the information of 81 families (1,675 individuals) ascertained from a Brazilian family study [6] of cardiovascular risk factors to investigate the heterogeneity in the genetic and environmental contributions to variations in six quantitative cardiovascular risk factors (systolic and diastolic blood pressure, LDLand HDL-cholesterol, fasting glucose, and triglycerides) by comparing variance components between males and females, and between young and old people. In order to compare our findings with those obtained by [1] we considered the sample median age of 43 years as the cutoff between young and old individuals.

\section{Methods}

\section{Data set}

The data analyzed here are from 81 families of the Baependi Family Heart Study [6]. The data were collected in accordance with a planned sample design from December 2005 to January 2006 in the rural village of Baependi (18,072 inhabitants) located in the state of Minas Gerais, Brazil. All participants provided written informed consent for the collection of samples and subsequent analysis. The study included several stages and was approved by the ethics committee of the Hospital das Clinicas, University of Sao Paulo, Brazil. At the first stage, eleven census districts were selected from among the twelve geographical divisions of Baependi. Next, residential addresses were randomly selected within the districts identified. An individual
18 years or older within each selected household was interviewed, following which all his/her first, second and third degree relatives and his/her respective spouse's relatives that were at least 18 years old were invited to participate in the study. A total of 1,672 individuals from 119 families were interviewed for this study. Each participant provided information regarding family relationships, demographic characteristics, medical history and environmental risk factors. Trained medical students also performed a physical examination and electrocardiogram for each participant. Standard techniques were used for measuring height, weight, blood pressure, fasting blood glucose, total cholesterol, lipoprotein fractions, and triglycerides. Mean values of systolic and diastolic blood pressures were calculated from three measurements taken at three minute intervals.

Considering that families with only one or two individuals cannot provide much information for family studies, we analyzed data from 81 families involving 1,675 people, $43.5 \%$ of whom were male. The maximum number of generations per family was four, and the minimum was two $(54 \%$ of the families had three generations, and $45 \%$ had two). In addition, 630 nuclear families were observed as well as 3106 parent-offspring relationships and 2552 grandparent-grandchild relationships. Family size varied from three to 157 individuals, with the average being 21 per family. About $4 \%$ of individuals were on lipid-lowering medications, $4 \%$ were on hypoglycemic medications, and $24 \%$ were on anti-hypertensive medications. Obesity and being overweight were predominant among women due to their sedentary lifestyles. Several descriptive statistics for the individuals analyzed are shown in Table 1.

\section{Statistical Analyses \\ Polygenic model}

Consider $y_{i}$ the measured trait value of the $i$ th individual, $i=1, \ldots, n$, where sets of individuals are grouped

Table 1 Descriptive statistics of 1,675 individuals from 81 Brazilian families

\begin{tabular}{|c|c|c|c|}
\hline & Total $(\mathrm{N}=1675)$ & Men $(N=729)$ & Women $(\mathrm{N}=946)$ \\
\hline Age (years) & $44.0(16.9)$ & $44.5(17.5)$ & $43.6(16.5)$ \\
\hline BMI $\left(\mathrm{kg} / \mathrm{m}^{2}\right)$ & $24.4(4.80)$ & $23.4(3.80)$ & $25.2(5.30)$ \\
\hline Fasting glucose (mg/dL) & $93.7(30.0)$ & $93.1(26.5)$ & $94.2(32.0)$ \\
\hline Triglycerides (mg/dL) & $133.3(75.4)$ & $134.8(82.6)$ & $132.2(69.3)$ \\
\hline $\mathrm{HDL}-\mathrm{c}(\mathrm{mg} / \mathrm{dL})$ & $55.9(15.6)$ & $53.9(15.3)$ & $57.5(15.7)$ \\
\hline LDL-c (mg/dL) & $98.7(44.1)$ & $96.0(43.8)$ & $100.7(44.2)$ \\
\hline Systolic blood pressure (mmHg) & $126.8(19.4)$ & $130.3(18.7)$ & $124.1(19.4)$ \\
\hline Diastolic blood pressure $(\mathrm{mmHg})$ & $78.7(11.4)$ & $79.4(11.6)$ & $78.3(11.2)$ \\
\hline Smokers (\%) & 16.6 & 20.6 & 13.5 \\
\hline Sedentary lifestyle (\%) & 21.1 & 17.8 & 23.7 \\
\hline
\end{tabular}

Mean values and standard deviations are provided for quantitative traits and \% is provided for qualitative traits. 
into $k$ families of $n_{f}$ relatives $(f=1, \ldots, k)$. Under the polygenic model, $y_{i}$ is expressed as

$$
y_{i}=\mu+\sum_{j=1}^{p} \beta_{j} X_{i j}+g_{i}+e_{i}
$$

where $\mu$ is the general mean of the trait and $\beta_{j}$ is the regression coefficient for covariate $j$ which assumes the value $X_{i j}$ for individual $i$. The remaining components, $g_{i}$ and $e_{i}$, are the residual genetic effect due to the polygenic term and random error component, respectively. The random effects, $g_{i}$ and $e_{i}$, are usually assumed to be uncorrelated and normally distributed with means of zero and variance $\sigma_{g}^{2}$ and $\sigma_{e}^{2}$, respectively. The environmental variance component, $\sigma_{e}^{2}$, is unique to each individual. Whereas the polygenic component, $\sigma_{g}^{2}$, is shared between individuals in proportion to their kinship coefficient. Thus, the covariance between traits for individuals $i$ and $i$ ' is given by:

$$
\operatorname{Cov}\left(y_{i^{\prime}}, y_{i^{\prime}}\right)=\left\{\begin{array}{lr}
\sigma_{g}^{2}+\sigma_{e}^{2} & \text { for } i=i^{\prime} \\
2 \phi_{i i^{\prime}} \sigma_{g}^{2} & \text { for } i \neq i^{\prime} \text { and related } \\
0 & \text { for } i \neq i^{\prime} \text { and unrelated }
\end{array}\right.
$$

Parameter $2 \varphi_{i i}$, is the coefficient of relationship between individuals $i$ and $i$ ' The likelihood of the traits of family members is assumed to follow a multivariate normal distribution. Estimates of the mean and variance components are obtained by using maximum likelihood methods $[7,8]$.

In order to test the hypotheses of polygenic effect, $\mathrm{H}_{0}$ : $\sigma_{g}^{2}=0$ against $\mathrm{H}_{0}: \sigma_{g}^{2}>0$, the likelihood ratio statistic can be used. This statistic is asymptotically distributed as a $(1 / 2):(1 / 2)$ mixture of $\chi_{1}^{2}$ and $\chi_{0}^{2}$ [9]. Under the polygenic model (1) heritability estimates $\left(h_{g}^{2}\right)$ due to the polygenic effect can be calculated as the proportion of the total variance of the phenotype explained by additive genetic effects after accounting for covariates, i.e. $h_{g}^{2}=\sigma_{g}^{2} /\left(\sigma_{g}^{2}+\sigma_{e}^{2}\right)$.

\section{Models with heterogeneity between the sexes}

To model heterogeneity between subgroups of individuals such as males and females, we can evaluate models with separate variance components. Evidence of heterogeneity by sex suggests that models allowing for these differences will be useful in mapping quantitative traits [1]. To evaluate the evidence for heterogeneity in genetic and environmental sources of variation in males and females, we assumed in the polygenic model (1) that $g_{i} \sim \mathrm{N}\left(0,1_{i} \sigma_{g, \text { female }}^{2}+\left(1-1_{i}\right) \sigma_{g \text {,male }}^{2}\right)$ and $e_{i} \sim \mathrm{N}\left(0,1_{i} \sigma_{e, \text { female }}^{2}+\left(1-1_{i}\right) \sigma_{e, \text { male }}^{2}\right)$, where $1_{i}$ is equal to 1 if the individual $i$ is female and 0 otherwise. Thus, the covariance between traits for individuals $i$ and $i^{\prime}$ is expressed as

$$
\operatorname{Cov}\left(y_{i}, y_{i^{\prime}}\right)= \begin{cases}\sigma_{g, \text { female }}^{2}+\sigma_{e, \text { female }}^{2} & i=i^{\prime} \text { and female } \\ \sigma_{g, \text { male }}^{2}+\sigma_{e, \text { male }}^{2} & i=i^{\prime} \text { and male } \\ 2 \phi_{i i^{\prime}} \sigma_{g, \text { female }}^{2} & i \neq i^{\prime}, \text { related and females } \\ 2 \phi_{i i^{\prime}} \sigma_{g, \text { male }}^{2} & i \neq i^{\prime}, \text { related and males } \\ 2 \phi_{i i^{\prime}} \sigma_{g, \text { female, male }}^{2} & i \neq i^{\prime}, \text { related and } \neq \text { sexes } \\ 0 & i \neq i^{\prime} \text { and unrelated. }\end{cases}
$$

When individuals $i$ and $i$ are related and of opposite sexes, two possible models were evaluated. In the first we assumed that the same set of genes, but with different effects, influence phenotypes for males and females. In this case, the covariance for individuals of opposite sexes was set as $\operatorname{Cov}\left(y_{i}, y_{i}\right)=2 \varphi_{i i} \sigma_{g, f e m a l e} \sigma_{g, \text { male }}$. In the second, we assumed that different sets of genes influence phenotypes for males and females. In this case, the covariance was set as $\operatorname{Cov}\left(y_{i}, y_{i}{ }^{\prime}\right)=2 \varphi_{i i} \rho_{\text {sex }} \sigma_{g, \text { female }}$ with $-1<\rho_{\text {sex }}<1$.

Considering the situation where $\rho_{\text {sex }}=1$, models for each cardiovascular trait were fitted taking into account (a) no covariates, (b) only the sex covariate, and (c) the sex and age covariates, simultaneously. For each of these three situations, four possibilities were considered with regard to the genetic and environmental variance components (v.c.):

1) homogeneity in both of v.c.
$\left(\sigma_{g, \text { female }}^{2}=\sigma_{g, \text { male }}^{2}=\sigma_{g}^{2}\right.$ and $\left.\sigma_{e, \text { female }}^{2}=\sigma_{e, \text { male }}^{2}=\sigma_{e}^{2}\right)$,

2) heterogeneity in at least one of the v.c. $\left(\sigma_{g, \text { female }}^{2} \neq \sigma_{g, \text { male }}^{2}\right.$ and $/$ or $\left.\sigma_{e, \text { female }}^{2} \neq \sigma_{e, \text { male }}^{2}\right)$,

3) heterogeneity only in the environmental v.c. $\left(\sigma_{g, \text { female }}^{2}=\sigma_{g, \text { male }}^{2}=\sigma_{g}^{2}\right.$ and $\left.\sigma_{e, \text { female }}^{2} \neq \sigma_{e, \text { male }}^{2}\right)$,

4) heterogeneity only in the genetic v.c. $\left(\sigma_{g, \text { female }}^{2} \neq \sigma_{g, \text { male }}^{2}\right.$ and $\left.\sigma_{e, \text { female }}^{2}=\sigma_{e, \text { male }}^{2}=\sigma_{e}^{2}\right)$.

Comparison and selection of the best model fitted with no covariates was performed, using tests based on the likelihood ratio statistic. Initially, the hypothesis $\mathrm{H}_{1}$ : homogeneity in both variance components was tested against $\mathrm{H}_{2}$ : heterogeneity in at least one of the variance components. In case of rejection of $\mathrm{H}_{1}$, conclusion about which variance component is heterogeneous (genetic, environmental or both) was taken after to test the hypothesis a) $\mathrm{H}_{1}$ against 
$\mathrm{H}_{3}$ : heterogeneity only in the environmental variance component; and b) $\mathrm{H}_{1}$ against $\mathrm{H}_{4}$ : heterogeneity only in the genetic variance component. The same strategy was used to compare and select the best model, including i) the sex covariate, and ii) sex and age covariates, simultaneously. The significance level assumed in this comparison and selection procedure was 0.05 .

\section{Models with heterogeneity between young and old individuals}

To evaluate heterogeneity in variance components by age, we classified individuals into two groups according to the median age in our sample (43 yrs). The younger group included individuals less than or equal to $43 \mathrm{yrs}$ old, and the older group included those above $43 \mathrm{yrs}$ of age. Similar to the model with heterogeneity between the sexes, we assumed in the polygenic model (1) that $g_{i} \sim \mathrm{N}\left(0,1_{i} \sigma_{g, \text { old }}^{2}+\left(1-1_{i}\right) \sigma_{g, \text { young }}^{2}\right)$ and $e_{i} \sim \mathrm{N}\left(0,1_{i} \sigma_{e, \text { old }}^{2}+\left(1-1_{i}\right) \sigma_{e, \text { young }}^{2}\right)$, where $1_{i}$ is equal to 1 if the individual $i$ is in the older group and 0 otherwise. The covariance between traits for individuals $i$ and $i$ ' is expressed in a similar way as previously described for sex. In this case, the fitted models included (a) no covariates, (b) the age covariate only, and (c) the sex and age covariates, simultaneously. Regarding the genetic and environmental variance components, the possibilities considered were similar to those described for sex with $\sigma_{g, \text { female }}^{2}, \sigma_{g, \text { male }}^{2}, \sigma_{e, \text { female }}^{2}$ and $\sigma_{e, \text { male }}^{2}$ replaced by $\sigma_{g, \text { old }}^{2}, \sigma_{g, \text { young }}^{2} \sigma_{e, \text { old }}^{2}$ and $\sigma_{e, \text { young }}^{2}$ respectively. Models allowing different sets of genes that influence phenotypes in young and old individuals were also investigated. A comparison and selection of the best model was performed in the same manner described for sex.

\section{Results}

\section{Descriptive statistics}

To examine the effect of sex and age on each trait, we generated summary plots for the six traits considered in this paper without considering family structure. Figure 1 displays the distribution of these traits for males and females. From this figure, it is clear that there are no marked differences between the sexes regarding their overall distribution for all traits with the exception of systolic blood pressure. Figure 2 illustrates the effect of

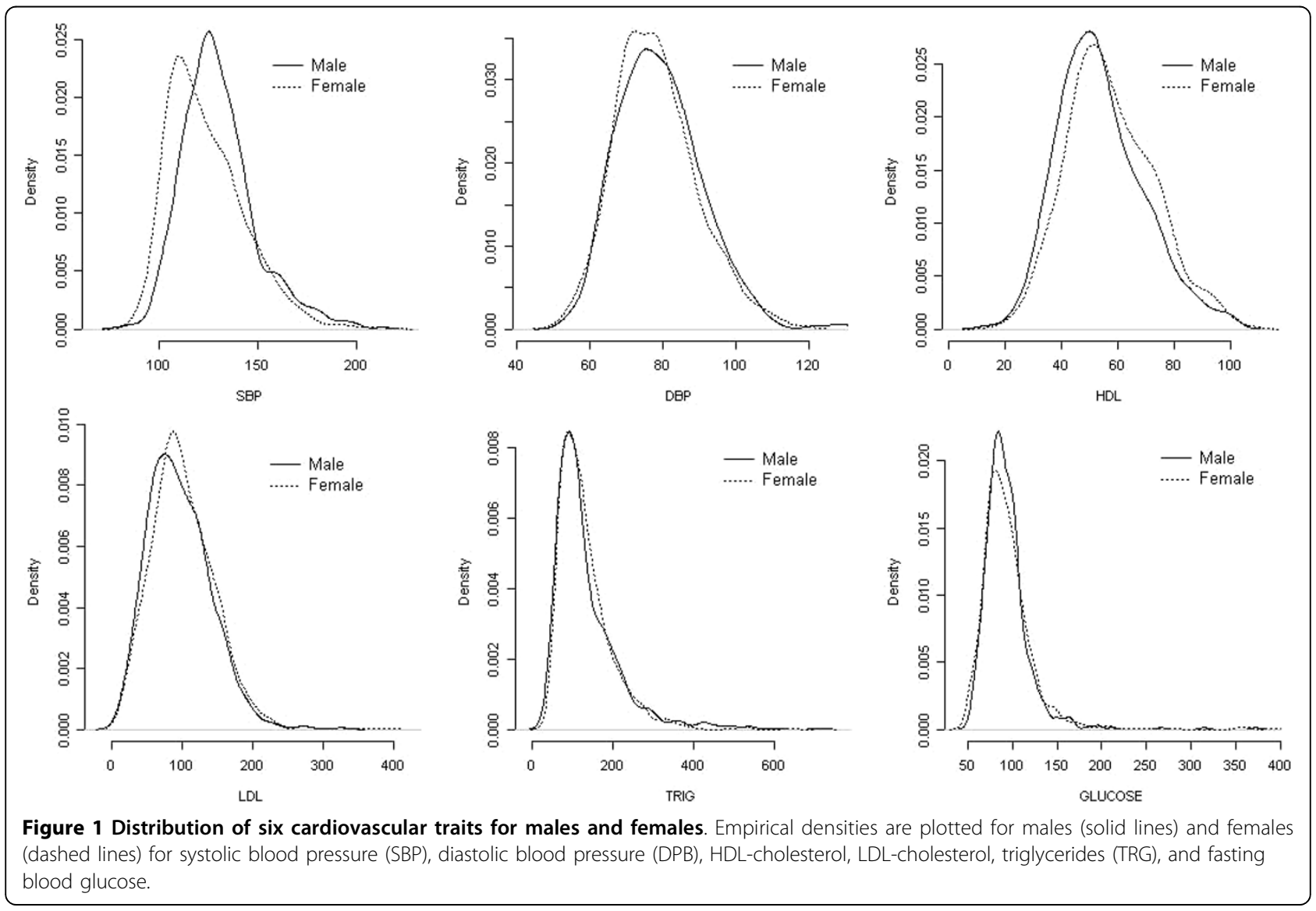



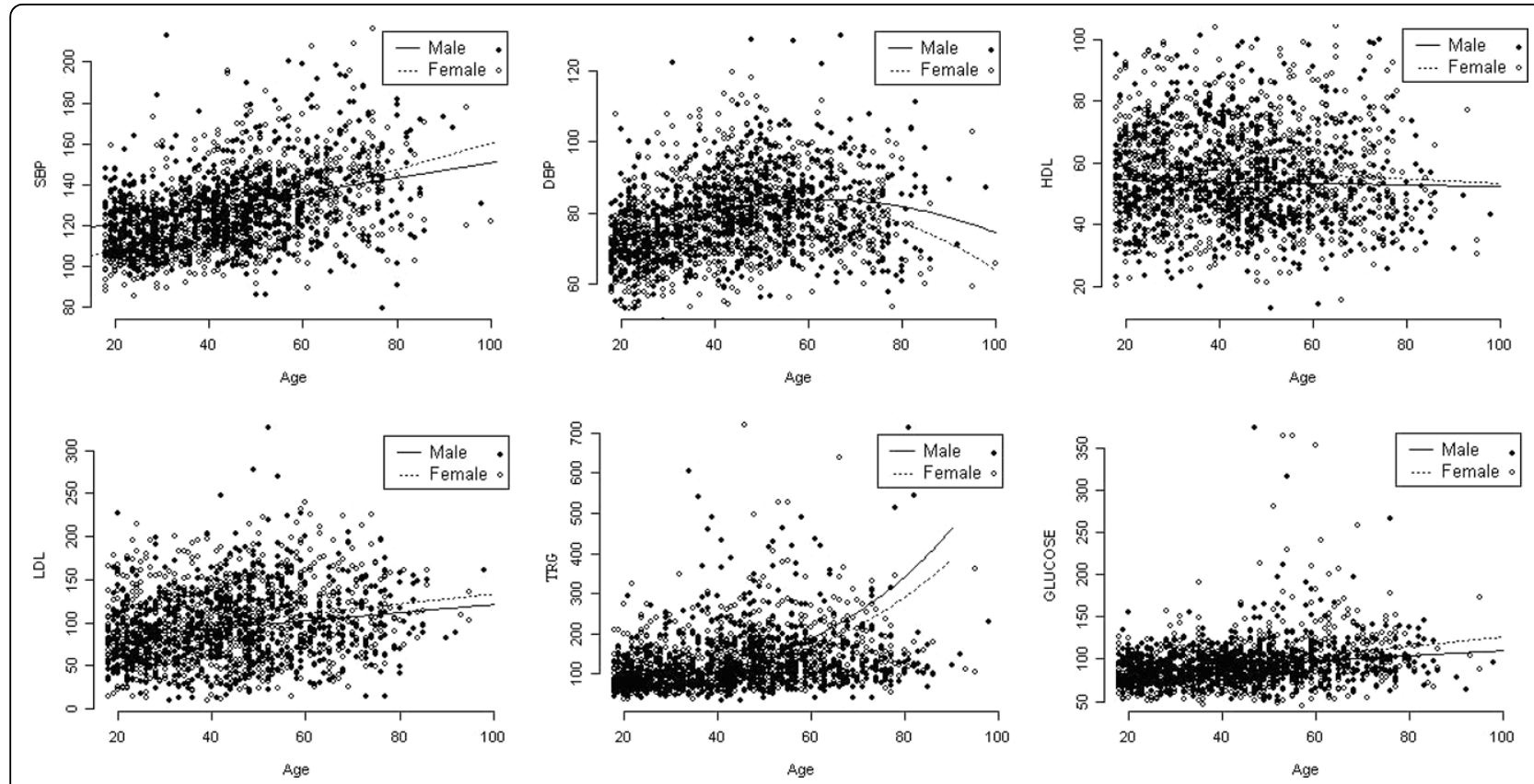

Figure 2 Values of six cardiovascular traits plotted for males (closed circles) and females (open circles) as a function of age in years. Regression curves fitted to the data show trends for males (solid lines) and females (dashed lines) with increasing age.

age on the same six traits. Regression curves are presented to summarize the effect of age on the traits. Linear trends are observed for four traits (systolic blood pressure, HDL- and LDL-cholesterol, and fasting glucose).

In addition, Figure 3 displays a simple graphic representation [10] that sometimes can be useful for exploring possible heterogeneity in the genetic variance. From graph (A), where the values of the trait $\ln (\mathrm{SBP})$ are plotted for each family ordered according to their respective trait means, we note that the mean values associated with the families vary from the overall mean value (horizontal dashed line). This suggests the prevalence of between-family heterogeneity and within-family correlations because, in general, the responses for a family tend to lie on the same side of the overall mean

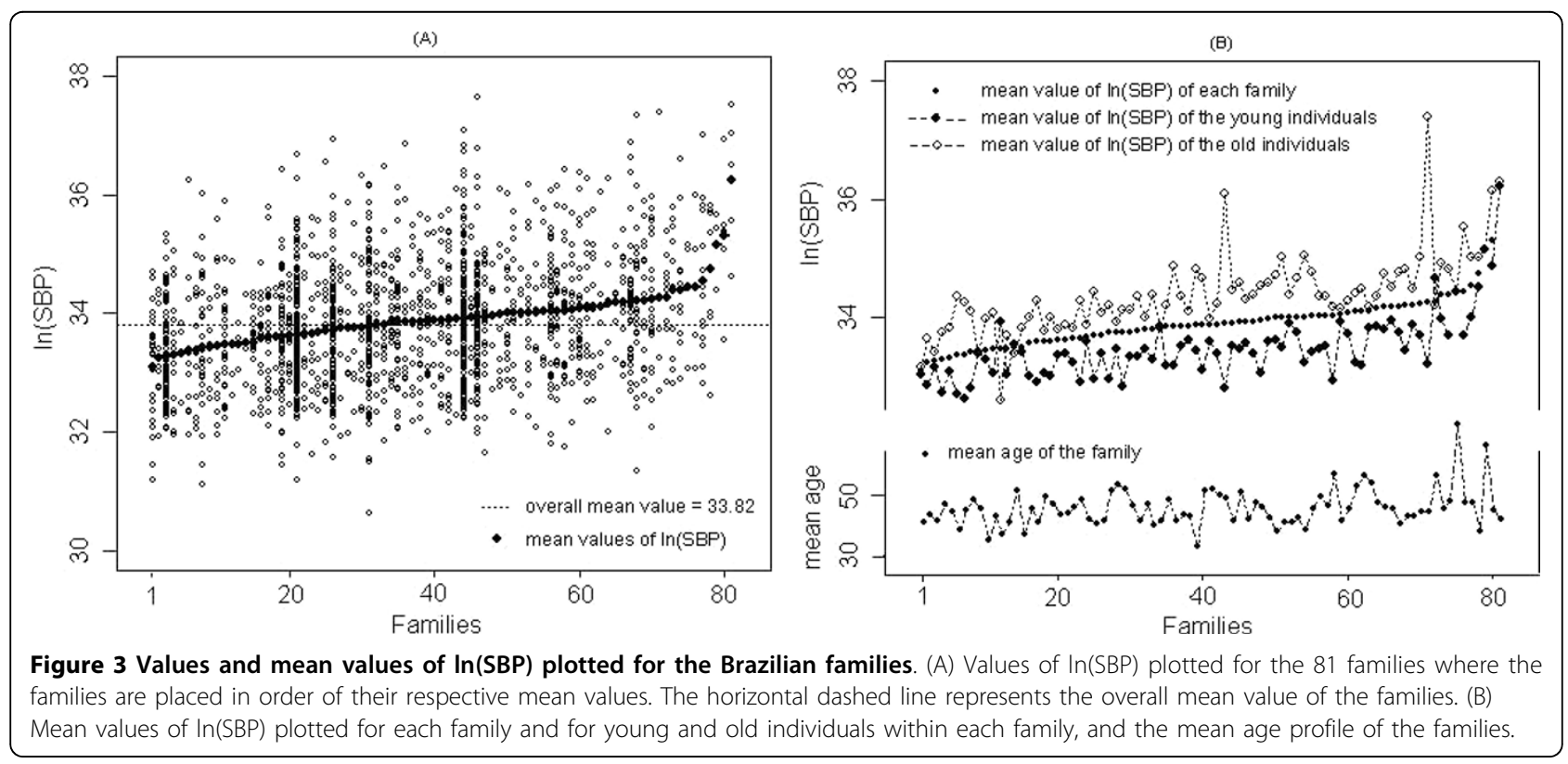


value. From graph (B), it is also possible to see that this pattern of heterogeneity remains, for instance, even after conditioning on young and old age groups. We note that the mean values for individuals in the older group are in general, above the overall mean value. The reverse can be observed for individuals in the younger group. In addition, such a trend is not associated with the mean age profile of the families as displayed in graph (B).

Table 2 displays the mean values and standard deviations of all cardiovascular traits for the entire sample, and for the sample stratified by age and sex simultaneously. The sample median age ( $43 \mathrm{yrs}$ ) was used to classify by age. As expected, trait mean values are, in general, higher for individuals in the older group $(>43$ yrs old). Except for HDL-cholesterol, differences in the mean values within sex between age groups were statistically significant at $5 \%$.

\section{Heterogeneity in variance components by sex}

Since $24 \%$ of subjects were on antihypertensive medication, $4 \%$ on lipid lowering medication, and $4 \%$ on hypoglycaemic medication, a correction factor was applied to those subjects taking medication. This approach has been shown to be superior to ignoring the treatment or to excluding individuals on therapy [11]. In this paper, individuals treated for hypertension were imputed to have $10 \mathrm{~mm} \mathrm{Hg}$ higher SBP and $5 \mathrm{~mm} \mathrm{Hg}$ higher DBP than the observed measurements [12,13]. Similarly, individuals on lipid lowering medication were imputed to have $50 \mathrm{mg} / \mathrm{dl}$ higher LDL-cholesterol, $10 \mathrm{mg} / \mathrm{dl}$ lower HDL-cholesterol and $30 \mathrm{mg} / \mathrm{dl}$ higher triglycerides [14,15]. A fixed increment of $30 \mathrm{mg} / \mathrm{dl}$ was added to the glucose measurements of those individuals on hypoglycaemic medication $[16,17]$.

After correcting the observed measurements of those subjects taking medication, a series of models was fitted for all traits where heterogeneity in males and females was allowed in polygenic variance component only, in environmental variance component only, and in both variance components. The models were fitted by considering no covariates, the sex covariate only, and sex and age covariates, simultaneously. Although, for DBP and triglycerides, it was suggested (Figure 2) that age ${ }^{2}$ should be considered in the models, no significant evidence was found to retain it or the interaction between age and sex in the models. Natural log-transformation was applied for all traits in order to have the required normality assumption achieved. For traits where even after transformations the residual kurtosis remained too high, we tried to prevent biased heritability estimates using a robust estimation implemented in SOLAR through the $t$-dist procedure [18]. Under this procedure, the $t$-Student distribution is used in the place of the normal distribution. From fitted models with $\rho_{\text {sex }} \neq 1$ (not shown), we found no evidence that different sets of genes contribute to genetic variation in males and females. Thus, the results shown in Table 3 are only for the models assuming that the same set of genes influence phenotypes for males and females, i.e. $\rho_{\text {sex }}=1$, and selected by using the comparison procedure based on likelihood ratio tests described previously.

From the selected models presented in Table 3, we observed no significant evidence for heterogeneity of the genetic and environmental variance components in males and females for three traits (diastolic blood pressure, LDL and HDL-cholesterol) either in the presence or absence of the covariates considered. For the fasting glucose trait, models with heterogeneity in both genetic and environmental variance components were selected when either no covariates or the sex covariate was included in the model. In the presence of sex and age covariates, a model with heterogeneity only in the genetic variance component was suggested. Thus, heterogeneity in genetic variance components by sex for this trait does not depend on the covariates included in the model. Models for the triglycerides trait including either no covariates or the sex covariate suggested evidence of heterogeneity in both genetic and

Table 2 Summary statistics for the entire sample and stratified by sex and age

\begin{tabular}{|c|c|c|c|c|c|c|c|c|c|c|}
\hline \multirow[b]{4}{*}{ Traits } & \multicolumn{2}{|c|}{ Overall } & \multicolumn{4}{|c|}{ Males $(\mathrm{N}=729)$} & \multicolumn{4}{|c|}{ Females $(\mathrm{N}=946)$} \\
\hline & & & \multirow{2}{*}{\multicolumn{2}{|c|}{$\begin{array}{c}\text { Young } \\
N=366\end{array}$}} & \multirow{2}{*}{\multicolumn{2}{|c|}{$\begin{array}{c}\text { Old } \\
N=363\end{array}$}} & \multirow{2}{*}{\multicolumn{2}{|c|}{$\begin{array}{l}\text { Young } \\
N=489\end{array}$}} & \multirow{2}{*}{\multicolumn{2}{|c|}{$\begin{array}{c}\text { Old } \\
\mathrm{N}=457\end{array}$}} \\
\hline & \multicolumn{2}{|c|}{$N=1675$} & & & & & & & & \\
\hline & Mean & s.d. & mean & s.d. & mean & s.d. & mean & s.d. & mean & s.d. \\
\hline $\mathrm{SBP}(\mathrm{mm} \mathrm{Hg})$ & 126.8 & 19.4 & 124.8 & 13.6 & 135.7 & 21.5 & 115.2 & 14.5 & 133.5 & 19.7 \\
\hline $\mathrm{DBP}(\mathrm{mm} \mathrm{Hg})$ & 78.7 & 11.4 & 75.8 & 9.7 & 82.9 & 12.3 & 75.2 & 10.5 & 81.6 & 10.8 \\
\hline $\mathrm{HDL}(\mathrm{mg} / \mathrm{dL})$ & 55.9 & 15.6 & 54.6 & 14.9 & 53.2 & $15.5 * *$ & 58.3 & 15.3 & 56.5 & $16.0 * *$ \\
\hline LDL (mg/dL) & 98.7 & 44.1 & 87.7 & 39.0 & 104.5 & 46.7 & 93.7 & 39.6 & 108.1 & 47.5 \\
\hline TRG (mg/dL) & 133.3 & 75.4 & 118.4 & 73.9 & 151.3 & 87.5 & 111.7 & 49.2 & 153.9 & 80.2 \\
\hline GLU (mg/dL) & 93.7 & 29.6 & 87.7 & 17.1 & 98.7 & 32.5 & 86.6 & 18.8 & 102.2 & 39.9 \\
\hline
\end{tabular}

SBP = systolic blood pressure, DBP = diastolic blood pressure, HDL- and LDL-cholesterol, TRG = triglycerides, GLU = fasting glucose, $\leq 43$ yrs $=$ young and $>43$ yrs $=$ old. ${ }^{* *}$ Except for HDL-cholesterol, differences in the mean values within sex between age groups were statistically significant at $5 \%$ according to the t-test. 
Table 3 Summary of the results obtained for models selected in the analysis of heterogeneity in variance components by sex

\begin{tabular}{|c|c|c|c|c|c|c|c|c|c|c|c|}
\hline \multirow{3}{*}{ Traits } & \multirow{3}{*}{ Covariates } & \multicolumn{3}{|c|}{ No Heterogeneity } & \multirow{3}{*}{$\begin{array}{l}\text { Selected model } \\
\text { variance with } \\
\text { heterogeneity }\end{array}$} & \multicolumn{6}{|c|}{ Heterogeneity in Variance Components by Sex } \\
\hline & & \multirow{2}{*}{$\begin{array}{c}\text { Polygenic } \\
\text { heritability } \\
\text { estimates } \\
h^{2}(s d)\end{array}$} & \multicolumn{2}{|c|}{$\begin{array}{l}\text { Estimates of polygenic } \\
\text { and environmental variances }\end{array}$} & & \multicolumn{2}{|c|}{$\begin{array}{l}\text { Polygenic heritability } \\
\text { estimates }\end{array}$} & \multicolumn{4}{|c|}{$\begin{array}{l}\text { Estimates of polygenic and } \\
\text { environmental variances }\end{array}$} \\
\hline & & & $\hat{\sigma}_{g}^{2}$ & $\hat{\sigma}_{e}^{2}$ & & $\begin{array}{c}\text { Male } \\
\mathrm{h}_{\mathrm{m}}^{2}\end{array}$ & $\begin{array}{c}\text { Female } \\
\mathrm{h}_{\mathrm{f}}^{2}\end{array}$ & $\hat{\sigma}_{g, m}^{2}$ & $\hat{\sigma}_{e, m}^{2}$ & $\hat{\sigma}_{g, f}^{2^{\text {Fem }}}$ & $\begin{array}{l}\text { nale } \\
\qquad \hat{\sigma}_{e, f}^{2}\end{array}$ \\
\hline $\ln (\mathrm{SBP})$ & $\begin{array}{l}\text { No } \\
\text { Sex } \\
\text { Sex, Age }\end{array}$ & $\begin{array}{l}0.1412(0.034) \\
0.1442(0.034) \\
0.2685(0.041)\end{array}$ & $\begin{array}{l}0.1783 \\
0.1790 \\
0.2499\end{array}$ & $\begin{array}{l}1.0841 \\
1.0622 \\
0.6808\end{array}$ & $\begin{array}{c}\text { environmental } \\
\text { environmental } \\
\text { no heterogeneity }\end{array}$ & $\begin{array}{l}0.1678 \\
0.1707 \\
0.2685\end{array}$ & & $\begin{array}{l}0.1847 \\
0.1843 \\
0.2499\end{array}$ & $\begin{array}{l}0.9158 \\
0.8954 \\
0.6808\end{array}$ & $\begin{array}{l}0.1847 \\
0.1843 \\
0.2499\end{array}$ & $\begin{array}{l}1.2052 \\
1.1834 \\
0.6808\end{array}$ \\
\hline $\ln (\mathrm{DBP})$ & $\begin{array}{l}\text { No } \\
\text { Sex } \\
\text { Sex, Age }\end{array}$ & $\begin{array}{l}0.1484(0.036) \\
0.1485(0.036) \\
0.2305(0.041)\end{array}$ & $\begin{array}{l}0.1645 \\
0.1645 \\
0.2241\end{array}$ & $\begin{array}{l}0.9436 \\
0.8432 \\
0.7479\end{array}$ & $\begin{array}{l}\text { no heterogeneity } \\
\text { no heterogeneity } \\
\text { no heterogeneity }\end{array}$ & & & $\begin{array}{l}0.1645 \\
0.1645 \\
0.2241\end{array}$ & $\begin{array}{l}0.9436 \\
0.8432 \\
0.7479\end{array}$ & $\begin{array}{l}0.1645 \\
0.1645 \\
0.2241\end{array}$ & $\begin{array}{l}0.9436 \\
0.8432 \\
0.7479\end{array}$ \\
\hline $\ln (\mathrm{GLU})$ & $\begin{array}{l}\Delta \text { No } \\
\Delta \text { Sex } \\
\Delta \text { Sex, Age }\end{array}$ & $\begin{array}{l}0.3401(0.046) \\
0.3401(0.046) \\
0.3570(0.048)\end{array}$ & $\begin{array}{l}0.3250 \\
0.3250 \\
0.3136 \\
\end{array}$ & $\begin{array}{l}0.6305 \\
0.6305 \\
0.5648 \\
\end{array}$ & $\begin{array}{c}\text { both } \\
\text { both } \\
\text { genetic }\end{array}$ & $\begin{array}{l}0.3184 \\
0.3181 \\
0.2865 \\
\end{array}$ & $\begin{array}{l}0.3520 \\
0.3522 \\
0.4142 \\
\end{array}$ & $\begin{array}{l}0.2635 \\
0.2632 \\
0.2251 \\
\end{array}$ & $\begin{array}{l}0.5640 \\
0.5642 \\
0.5605 \\
\end{array}$ & $\begin{array}{l}0.3744 \\
0.3747 \\
0.3964\end{array}$ & $\begin{array}{l}0.6891 \\
0.6891 \\
0.5605 \\
\end{array}$ \\
\hline $\ln (\mathrm{LDL})$ & $\begin{array}{l}\Delta \text { No } \\
\Delta \text { Sex } \\
\Delta \text { Sex, Age }\end{array}$ & $\begin{array}{l}0.2956(0.049) \\
0.2946(0.049) \\
0.2966(0.050)\end{array}$ & $\begin{array}{l}0.2903 \\
0.2865 \\
0.2751\end{array}$ & $\begin{array}{l}0.6918 \\
0.6860 \\
0.6522\end{array}$ & $\begin{array}{l}\text { no heterogeneity } \\
\text { no heterogeneity } \\
\text { no heterogeneity }\end{array}$ & $\begin{array}{l}0.2956 \\
0.2946 \\
0.2966\end{array}$ & $\begin{array}{l}0.2956 \\
0.2946 \\
0.2966\end{array}$ & $\begin{array}{l}0.2903 \\
0.2865 \\
0.2751\end{array}$ & $\begin{array}{l}0.6918 \\
0.6860 \\
0.6522\end{array}$ & $\begin{array}{l}0.2903 \\
0.2865 \\
0.2751\end{array}$ & $\begin{array}{l}0.6918 \\
0.6860 \\
0.6522\end{array}$ \\
\hline $\ln (\mathrm{HDL})$ & $\begin{array}{l}\Delta \text { No } \\
\Delta \text { Sex } \\
\Delta \text { Sex, Age }\end{array}$ & $\begin{array}{l}0.3209(0.047) \\
0.3207(0.048) \\
0.3323(0.049)\end{array}$ & $\begin{array}{l}0.4134 \\
0.4096 \\
0.4207\end{array}$ & $\begin{array}{l}0.8747 \\
0.8674 \\
0.8452\end{array}$ & $\begin{array}{l}\text { no heterogeneity } \\
\text { no heterogeneity } \\
\text { no heterogeneity }\end{array}$ & $\begin{array}{l}0.3209 \\
0.3207 \\
0.3323\end{array}$ & $\begin{array}{l}0.3209 \\
0.3207 \\
0.3323\end{array}$ & $\begin{array}{l}0.4134 \\
0.4096 \\
0.4207\end{array}$ & $\begin{array}{l}0.8747 \\
0.8674 \\
0.8452\end{array}$ & $\begin{array}{l}0.4134 \\
0.4096 \\
0.4207\end{array}$ & $\begin{array}{l}0.8747 \\
0.8674 \\
0.8452\end{array}$ \\
\hline $\ln (T R G)$ & $\begin{array}{l}\text { No } \\
\text { Sex } \\
\text { Sex, Age }\end{array}$ & $\begin{array}{l}0.2590(0.044) \\
0.2585(0.044) \\
0.2863(0.047)\end{array}$ & $\begin{array}{l}0.2338 \\
0.2333 \\
0.2328\end{array}$ & $\begin{array}{l}0.6687 \\
0.6690 \\
0.5803\end{array}$ & $\begin{array}{c}\text { both } \\
\text { both } \\
\text { environmental }\end{array}$ & $\begin{array}{l}0.2662 \\
0.2653 \\
0.2507\end{array}$ & $\begin{array}{l}0.2563 \\
0.2560 \\
0.3324\end{array}$ & $\begin{array}{l}0.2694 \\
0.2684 \\
0.2370\end{array}$ & $\begin{array}{l}0.7425 \\
0.7430 \\
0.7082\end{array}$ & $\begin{array}{l}0.2097 \\
0.2095 \\
0.2370\end{array}$ & $\begin{array}{l}0.6085 \\
0.6087 \\
0.4759\end{array}$ \\
\hline
\end{tabular}

$\mathrm{SBP}=$ systolic blood pressure, $\mathrm{DBP}=$ diastolic blood pressure, $\mathrm{GLU}=$ fasting glucose, $\mathrm{LDL}=\mathrm{LDL}$-cholesterol, $\mathrm{HDL}=\mathrm{HDL}$-cholesterol. $\mathrm{TRG}=$ triglycerides, $\Delta=$ the t-dist procedure used in SOLAR, $\hat{\sigma}_{g}^{2}$ and $\hat{\sigma}_{e}^{2}$ are estimates of polygenic and environmental variances, $\hat{\sigma}_{g, m}^{2}$ and $\hat{\sigma}_{g, f}^{2}$ are estimates of male and female polygenic variances, $\hat{\sigma}_{e, m}^{2}$ and $\hat{\sigma}_{e, f}^{2}$ are estimates of male and female environmental variances. Significance level of 5\% was used in the comparison and selection procedure of the best model.

environmental variances, while models including sex and age covariates, simultaneously, indicated heterogeneity only in the environmental variance. For the systolic blood pressure (SBP) trait, no heterogeneity in either variance was suggested from model that included the sex and age covariates. In addition, models without the age covariate suggested evidence of heterogeneity only in the environmental variance.

Regarding the polygenic heterogeneity due to sex, two scenarios are highlighted from our results. The first shows genetic heterogeneity in the fasting glucose trait that was maintained independent of the adjustment of the phenotypic mean by covariates. The second scenario shows heterogeneity due to sex in the triglycerides trait that is dependent on age in such a way that if the age effect is adjusted in the phenotypic mean, the effect in the genetic variance component disappears.

In the cases where heterogeneity in the genetic variance component was suggested (fasting glucose and triglycerides traits), higher polygenic heritability between females was observed for fasting glucose.
Heterogeneity in variance components by age groups

With the purpose of comparing our findings, in terms of the heterogeneity pattern, with those obtained in the cohort of Sardinians [1], it was considered, similar to the Sardinia study, the sample median age (43 yrs) as the cutoff between young and old individuals. Our main interest in this comparison relies on the fact that the Brazilian population has experienced a high level of miscegenation over the centuries $[19,20]$ while the Sardinia population constitutes a genetically isolated founder population [1].

Table 4 displays the results obtained for the same six traits (also after correcting the observed measurements of those subjects taking medication) when heterogeneity for individuals in younger and older groups was allowed in variance components. Results are for the selected models assuming that the same genes influence phenotypes for young and old people $\left(\rho_{\text {age }}=1\right)$ since the opposite was not suggested from the fitted models. As before, models were fitted by considering no covariates, the age covariate only, and the sex and age covariates, 
Table 4 Summary of the results obtained for models selected in the analysis of heterogeneity in variance components by age

\begin{tabular}{|c|c|c|c|c|c|c|c|c|c|c|c|}
\hline \multirow{4}{*}{ Traits } & \multirow{4}{*}{ Covariates } & \multicolumn{3}{|c|}{ No Heterogeneity } & \multirow{4}{*}{$\begin{array}{l}\text { Selected model } \\
\text { variance with heterogeneity }\end{array}$} & \multicolumn{6}{|c|}{$\begin{array}{l}\text { Heterogeneity in Variance Components by Groups } \\
\text { of Age }\end{array}$} \\
\hline & & \multirow{3}{*}{$\begin{array}{l}\text { Polygenic } \\
\text { heritability } \\
\text { estimates } \\
h^{2} \text { (s.d.) }\end{array}$} & \multicolumn{2}{|c|}{$\begin{array}{c}\text { Estimates of } \\
\text { polygenic } \\
\text { and environmental } \\
\text { variances }\end{array}$} & & \multicolumn{2}{|c|}{$\begin{array}{l}\text { Polygenic } \\
\text { heritability } \\
\text { estimates }\end{array}$} & \multicolumn{4}{|c|}{$\begin{array}{l}\text { Estimates of polygenic and } \\
\text { environmental variances }\end{array}$} \\
\hline & & & & & & \multirow{2}{*}{$\begin{array}{c}\text { Young } \\
\mathrm{h}_{\mathrm{y}}^{2}\end{array}$} & \multirow{2}{*}{$\begin{array}{l}\text { Old } \\
\mathrm{h}_{\mathrm{o}}^{2}\end{array}$} & \multicolumn{2}{|c|}{ Young } & \multicolumn{2}{|c|}{ Old } \\
\hline & & & $\hat{\sigma}_{g}^{2}$ & $\hat{\sigma}_{e}^{2}$ & & & & $\hat{\sigma}_{g, \gamma}^{2}$ & $\hat{\sigma}_{e, \gamma}^{2}$ & $\hat{\sigma}_{g, o}^{2}$ & $\hat{\sigma}_{e, o}^{2}$ \\
\hline $\ln (\mathrm{SBP})$ & $\begin{array}{l}\text { No } \\
\text { Age } \\
\text { Sex, Age }\end{array}$ & $\begin{array}{l}0.1412(0.034) \\
0.2647(0.041) \\
0.2685(0.041)\end{array}$ & $\begin{array}{l}0.1783 \\
0.2509 \\
0.2499\end{array}$ & $\begin{array}{l}1.0841 \\
0.6969 \\
0.6808\end{array}$ & & & $\begin{array}{l}0.1512 \\
0.2008 \\
0.2155\end{array}$ & & $\begin{array}{l}0.8477 \\
0.6468 \\
0.5639\end{array}$ & $\begin{array}{l}0.1510 \\
0.1625 \\
0.1549\end{array}$ & $\begin{array}{l}0.8477 \\
0.6468 \\
0.5639\end{array}$ \\
\hline $\ln (\mathrm{DBP})$ & $\begin{array}{l}\text { No } \\
\text { Age } \\
\text { Sex, Age }\end{array}$ & $\begin{array}{l}0.1484(0.036) \\
0.2306(0.041) \\
0.2305(0.041)\end{array}$ & $\begin{array}{l}0.1645 \\
0.2242 \\
0.2241\end{array}$ & & & & & & & & \\
\hline $\ln (G L U)$ & $\begin{array}{l}\Delta \text { No } \\
\Delta \text { Age } \\
\Delta \text { Sex, Age } \\
\end{array}$ & $\begin{array}{l}0.3401(0.046) \\
0.3571(0.048) \\
0.3570(0.048)\end{array}$ & $\begin{array}{l}0.3250 \\
0.3137 \\
0.3136 \\
\end{array}$ & $\begin{array}{l}0.6305 \\
0.5647 \\
0.5648 \\
\end{array}$ & $\begin{array}{l}\text { environmental } \\
\text { environmental } \\
\text { environmental }\end{array}$ & $\begin{array}{l}0.9554 \\
0.9324 \\
0.9330\end{array}$ & $\begin{array}{l}0.5058 \\
0.5093 \\
0.5095\end{array}$ & $\begin{array}{l}0.3346 \\
0.3163 \\
0.3163\end{array}$ & $\begin{array}{l}0.0156 \\
0.0229 \\
0.0227\end{array}$ & $\begin{array}{l}0.3346 \\
0.3163 \\
0.3163\end{array}$ & $\begin{array}{l}0.3269 \\
0.3047 \\
0.3045\end{array}$ \\
\hline $\ln (L D L)$ & $\begin{array}{l}\Delta \text { No } \\
\Delta \text { Age } \\
\Delta \text { Sex, Age }\end{array}$ & $\begin{array}{l}0.2956(0.049) \\
0.2983(0.050) \\
0.2966(0.050)\end{array}$ & $\begin{array}{l}0.2903 \\
0.2796 \\
0.2751\end{array}$ & $\begin{array}{l}0.6918 \\
0.6575 \\
0.6522\end{array}$ & $\begin{array}{l}\text { no heterogeneity } \\
\text { no heterogeneity } \\
\text { no heterogeneity }\end{array}$ & $\begin{array}{l}0.2956 \\
0.2983 \\
0.2966\end{array}$ & $\begin{array}{l}0.2956 \\
0.2983 \\
0.2966\end{array}$ & $\begin{array}{l}0.2903 \\
0.2796 \\
0.2751\end{array}$ & $\begin{array}{l}0.6918 \\
0.6575 \\
0.6522\end{array}$ & $\begin{array}{l}0.2903 \\
0.2796 \\
0.2751\end{array}$ & $\begin{array}{l}0.6918 \\
0.6575 \\
0.6522\end{array}$ \\
\hline $\ln (\mathrm{HDL})$ & $\begin{array}{l}\Delta \text { No } \\
\Delta \text { Age } \\
\Delta \text { Sex, Age }\end{array}$ & $\begin{array}{l}0.3209(0.047) \\
0.3323(0.048) \\
0.3323(0.049)\end{array}$ & $\begin{array}{l}0.4134 \\
0.4245 \\
0.4207\end{array}$ & $\begin{array}{l}0.8747 \\
0.8529 \\
0.8452\end{array}$ & $\begin{array}{l}\text { environmental } \\
\text { environmental } \\
\text { environmental }\end{array}$ & $\begin{array}{l}0.4547 \\
0.4467 \\
0.4546\end{array}$ & $\begin{array}{l}0.3652 \\
0.3729 \\
0.3755\end{array}$ & $\begin{array}{l}0.4276 \\
0.4357 \\
0.4325\end{array}$ & $\begin{array}{l}0.5126 \\
0.5395 \\
0.5188\end{array}$ & $\begin{array}{l}0.4276 \\
0.4357 \\
0.4325\end{array}$ & $\begin{array}{l}0.7430 \\
0.7327 \\
0.7193\end{array}$ \\
\hline $\ln (T R G)$ & $\begin{array}{l}\text { No } \\
\text { Age } \\
\text { Sex, Age }\end{array}$ & $\begin{array}{l}0.2590(0.044) \\
0.2874(0.047) \\
0.2863(0.047)\end{array}$ & $\begin{array}{l}0.2338 \\
0.2339 \\
0.2328\end{array}$ & $\begin{array}{l}0.6687 \\
0.5799 \\
0.5803\end{array}$ & $\begin{array}{l}\text { genetic } \\
\text { genetic } \\
\text { genetic }\end{array}$ & $\begin{array}{l}0.0843 \\
0.1263 \\
0.0268\end{array}$ & $\begin{array}{l}0.2680 \\
0.2385 \\
0.2600\end{array}$ & $\begin{array}{l}0.0633 \\
0.0826 \\
0.0169\end{array}$ & $\begin{array}{l}0.6875 \\
0.5714 \\
0.6130\end{array}$ & $\begin{array}{l}0.2518 \\
0.1790 \\
0.2154\end{array}$ & $\begin{array}{l}0.6875 \\
0.5714 \\
0.6130\end{array}$ \\
\hline
\end{tabular}

$\mathrm{SBP}=$ systolic blood pressure, $\mathrm{DBP}=$ diastolic blood pressure, $\mathrm{GLU}=$ fasting glucose, $\mathrm{LDL}=\mathrm{LDL}$-cholesterol, $\mathrm{HDL}=\mathrm{HDL}$-cholesterol. TRG $=$ triglycerides, $\Delta=$ the t-dist procedure used in SOLAR, $\hat{\sigma}_{g}$ and $\hat{\sigma}_{e}^{2}$ are estimates of polygenic and environmental variances, $\hat{\sigma}_{g, y}$ and $\hat{\sigma} g, o$ are estimates of young and old

polygenic variances, $\hat{\sigma}_{e, y}^{2}$ and $\hat{\sigma}_{e, o}^{2}$ are estimates of young and old environmental variances. Significance level of 5\% was used in the selection procedure of the best model.

simultaneously. Except for the LDL-cholesterol trait, the other traits showed evidence for heterogeneity in at least one of the variance components. For three traits (SBP, DBP and triglycerides), evidence of heterogeneity in the genetic variance was suggested independent of the covariates in the model. Higher polygenic heritability between old people was observed for these three traits (SBP, DBP and TRG). Evidence of heterogeneity only in the environmental variance component was suggested for fasting glucose and HDL-cholesterol independent of the covariates in the model.

\section{Discussion and Conclusions}

In the analysis of cardiovascular traits, we used information on 81 Brazilian families (1,675 individuals) to investigate the heterogeneity in variance components in subgroups of individuals. In particular, we investigated such heterogeneity by the two factors most commonly considered in the literature: sex and age. The sex and age dependency in the variances (as well as in the means) of the traits could indicate that different genetic and environmental factors may be influential in different sex-age cohorts [21]. Investigation of gene by sex interactions, for instance, is relevant because it may help to clarify differences on genetic susceptibilities and explain the sexual dimorphism of complex traits [5].

Here, we found evidence of age and/or sex differences in variance components for some of the cardiovascular traits analyzed. When analyzed by age, for instance, such differences affected the polygenic variance for triglycerides, and systolic and diastolic blood pressure, independent of the covariates in the models; but for fasting glucose and HDL-cholesterol, they affected the environmental variance. The age dependency in polygenic variance can be due to different magnitudes of the heritability with age or because different genes affect the trait at different ages [21]. Therefore, heterogeneity in variances should not be ignored in the analyses of these complex traits, even in the absence of genotypic data, since it may provide a strong argument for further research with the goal of mapping potentially different genes involved in males and females, as well as 
according to age. When genotypic data are available, more sophisticated models can be investigated for finding genes, such as the model including sex-specific oligogenic variance components (i.e. sex-specific components associated with major genes or QTL's). In an effort to illustrate the polygenic effect and its possible heterogeneity in subgroups of individuals as well as the possible covariate effects, we presented simple descriptive graphics in this work that may help in the understanding of the familial variation and correlation, although, in our illustrations, the genetic distances between individuals within families were not taken into account.

A point that can be highlighted from heterogeneity analysis is that care in the interpretation of the polygenic heritability is needed when genetic variance components are suggested to be homogeneous, but not the environmental variance components. In these cases, polygenic heritabilities will be, for instance, different by sex but only in a relative meaning due to environmental influences. In our study, this situation was observed in the evaluation of sex differences in the heritability of triglycerides.

In terms of the heterogeneity pattern, the results that we obtained for the Brazilian families in the Baependi Heart Study were similar to those obtained for the Sardinian families [1]. As in the Sardinian study, it was noted in our findings that two of the most heritable traits in the older group were systolic and diastolic blood pressure (SBP and DBP). The heterogeneity in variances for traits like these can be therefore too great to be ignored. Thus, modeling the variance heterogeneity between groups could be valuable in molecular studies. In such studies it may also be desirable to focus attention on the most informative individuals. For SBP and DBP traits, for instance, a very low heritability was observed for individuals less than 43 years of age. In this case, it could be therefore more fruitful to focus molecular studies on older individuals, since they showed higher heritability.

Overall, both this present study and other similar studies have supported sex and age differences in the polygenic effect on some cardiovascular traits [21]. The importance of identification of gene by sex and/or age interaction has therefore shown to suggest that, in the new genome era, it may contribute to the development of sex- and age-specific preventive and therapeutic strategies. The study of interactions, however, should not be restricted to the influence of sex and age groups. Other factors, e.g. race, should also be interesting to consider in the study of complex traits to increase the power of the analysis beyond pleiotropic influences [22].

In this paper we used the cutoff of 43 years between young and old. However, depending on the focus of the analysis, other cutoffs may be of greatest interest, since some of the sex-specific variation identified in serum lipids and other metabolic traits are tied to serum levels of sex hormones levels. Probably, and as has been recently proposed [23], the influence of continuous factors like age, commonly considered in groups, could provide more interesting information if considered as continuous in the study of gene by age interaction of complex traits. For this purpose, however, additional methodological and computational efforts may be needed.

\section{Acknowledgements}

The authors thank the reviewers and the associate editor for their comments and suggestions and the CNPq (Brazil, Grant 150653/2008-5) for partial financial support to the first author.

\section{Author details}

'Laboratory of Genetics and Molecular Cardiology, Heart Institute, Medical School of University of Sao Paulo, Sao Paulo, SP, Brazil. ${ }^{2}$ Department of Statistics, Federal University of Parana, Curitiba, PR, Brazil. ${ }^{3}$ Department of Health Sciences Research, Mayo Clinic, Rochester, MN, USA. ${ }^{4}$ Department of Statistics, University of Sao Paulo, Sao Paulo, SP, Brazil.

\section{Authors' contributions}

SRG, ACP and JPS performed the statistical analyses. SRG drafted the manuscript under the supervision of JPS, ACP, MA and JEK. ACP, JPS and JEK supervised the study. All authors read and approved the final manuscript.

\section{Competing interests}

The authors declare that they have no competing interests.

Received: 21 March 2009 Accepted: 20 September 2010

Published: 20 September 2010

\section{References}

1. Pilia G, Chen W-M, Scuteri A, Orrú M, et al: Heritability of cardiovascular and personality traits in 6,148 Sardinians. PLOS Genet 2006, 2:1207-1223.

2. Schousboe K, Willensen G, Kyvik KO, Mortensen J, Boomsma DI, Cornes BK, et al: Sex differences in heritability of BMI: a comparative study of results from twin studies in eight countries. Twin Res 2003, 6:409-421.

3. Harris JR, Tambis K, Magnus P: Sex-specific effects for body mass index in the Norwegian twin panel. Genet Epidemiol 1995, 12:251-265.

4. Boomsma DI, Kempen HJ, Gevers Leuven JA, Havekes L, de Knijff P, Francis RR: Genetic analysis of sex and generation differences in plasma lipid, lipoprotein, and apolipoprotein levels in adolescent twins and their parents. Genet Epidemiol 1996, 13:49-60.

5. MacCarthy JJ: Gene by sex interaction in the etiology of coronary heart disease and the preceding metabolic syndrome. Nutr Metab Cardiovasc Dis 2007, 17:153-161.

6. Oliveira CM, Pereira AC, de Andrade M, Soler JMP, Krieger JE: Heritability of cardiovascular risk factors in a Brazilian population: Baependi heart study. BMC Medical Genetics 2008, 9:32.

7. Almasy L, Blangero J: Multipoint quantitative-trait linkage analysis in general pedigrees. Am J Hum Genet 1998, 62:1198-1211.

8. de Andrade $\mathrm{M}, \mathrm{Amos} \mathrm{Cl}$, Thiel TJ: Methods to estimate genetic components of variance for quantitative traits in family studies. Genet Epidemiol 1999, 17:64-76.

9. Self SG, Liang K: Asymptotic properties of maximum likelihood estimators and likelihood ratio tests under nonstandard conditions. Am Stat AssoC 1987, 82:605-610.

10. Skrondal A, Rabe-Hesketh S: Generalized Latent Variable Modeling: Multilevel, Longitudinal, and Structural Equation Models. Boca Raton: Chapman \& Hall 2004.

11. Tobin MD, Sheehan NA, Scurrah KJ, Burton PR: Adjusting for treatment effects in studies of quantitative traits: antihypertensive therapy and systolic blood pressure. Statist Med 2005, 24:2911-2935. 
12. Cui JS, Hooper JL, Harrap SB: Antihypertensive treatments obscure familial contributions to blood pressure variation. Hypertension 2003, 41:207-210.

13. Newton-Cheh C, Johnson T, Gateva V, Tobin MD, Bochud M, Coin L, et al: Genome-wide association study identifies eight loci associated with blood pressure. Nat Genet 2009, 41:666-676.

14. Law MR, Wald NJ, Rudnicka : Quantifying effect of statins on low density lipoprotein cholesterol, ischaemic heart disease, and stroke: systematic review and meta-analysis. BMJ 2003, 326:1-7.

15. Edwards JE, Moore RA: Statins in hypercholesterolaemia: a dose-specific meta-analysis of lipid in randomised, double blind trials. BMC Family Practice 2003, 4:18

16. Belsey J, Krishnarajah G: Glycaemic control and adverse events in patients with type 2 diabetes treated with metformin + sulphonylurea: a metaanalysis. Diabetes, Obesity and Metabolism 2008, 10(Suppl 11):1-7.

17. Schaan BD, Harzheim E, Gus Iseu: Cardiac risk profile in diabetes mellitus and impaired fasting glucose. Rev Saúde Pública 2004, 38:529-536.

18. Solar: Sequential Oligogenic Linkage Analysis Routine for linux. [http:// solar.sfbrgenetics.org/].

19. Gonçalves VF, Carvalho CMB, Bartolini MC, Bydlowski SP, Pena SDJ: The Phylogeography of African Brazilians. Hum Hered 2008, 65:23-32.

20. Suarez-Kurtz G: Pharmacogenomics in Admixed Populations. Austin, TX: Landes Bioscience 2007.

21. Snieder H, Van Doornen LP, Boomsma DI: Dissecting the genetic architecture of lipids, lipoproteins, and apolipoproteins: lessons from twin studies. Arterioscler Thromb Vasc Biol 1999, 19:2826-2834.

22. Snieder H, Boomsma DI, Van Doornen LJP, Neale MC: Bivariate genetic analysis of fasting insulin and glucose levels. Genet Epidemiol 1999, 16:426-446.

23. Shi G, Gu CC, Kraja AT, Arnet DK, Myers RH, Pankow JS, Hunt SC, Rao DC: Modeling age variation in QTL effects leads to substantially improved linkage evidence for blood pressure in the HyperGEN study. Proceedings of the17th Annual Meeting of the International Genetic Epidemiology Society (IGES) St Louis, Missouri, USA 2008.

\section{Pre-publication history}

The pre-publication history for this paper can be accessed here: http://www.biomedcentral.com/1471-2350/11/132/prepub

doi:10.1186/1471-2350-11-132

Cite this article as: Giolo et al: Evaluating gene by sex and age interactions on cardiovascular risk factors in Brazilian families. BMC Medical Genetics 2010 11:132.

\section{Submit your next manuscript to BioMed Central and take full advantage of:}

- Convenient online submission

- Thorough peer review

- No space constraints or color figure charges

- Immediate publication on acceptance

- Inclusion in PubMed, CAS, Scopus and Google Scholar

- Research which is freely available for redistribution

Submit your manuscript at www.biomedcentral.com/submit
Ciomed Central 